\title{
Wear Simulation Modeling by Using the Finite Element Method
}

Zoran Pelagić ${ }^{1}$, Martin Nágel ${ }^{1}$, Milan Žmindák ${ }^{1}$, Daniel Riecky²

${ }^{1}$ Department of Applied Mechanics, Faculty of Mechanical Engineering, University of Žilina, Univerzitná 1, 010 26, Slovak Republic, Email: zoran.pelagic@fstroj.uniza.sk, martin.nagel@gmail.com, milan.zmindak@fstroj.uniza.sk, 2Plastic Omnium Auto Exteriors, Ltd., Slovak Republic, Email:daniel.riecky@plasticomnium.com

We can define wear as a phenomenon, which humanity can't fully explain and many do not understand it well. It is known for several millennia. It's an action, which can't be avoided. Often it's a critical factor affecting lifetime of device parts, for example the wear of plain bearings in many rotational devices can affect the function and cause great damage to it. The presented paper deals with stress and contact pressure distribution simulated by the finite element method (FEM) and the development of a wear module for simulating sliding wear of materials. First the theory of wear is presented. The next section presents the development of an own wear module in MATLAB, which also deals as an interface between MATLAB and ABAQUS software. Finally the module is tested on a sliding wear testing problem which is simulated using ABAQUS and the simulation results are presented at the end.

Keywords: Finite element method, wear, sliding contact

\section{Acknowledgement}

This work was supported by the Slovak Research and Development Agency under the contract No. APVV-0736-12.

\section{References}

[1] BENABDALLAH, H., OLENDER, D. (2006). Finite Element Simulation of the Wear of Polyoxymethylene in Pin-On-Disk Configuration, Wear 261, pp.1213-1224

[2] RABINOWICZ, E. (1995). Friction and Wear of Materials; 2nd ed. 336p. John Wiley \& Sons, New York

[3] MENG,H-C. (1994). Wear modelling: Evaluation and categorisation of wear models, Dissertation, University of Michigan. 165p

[4] HOLM, R. (1999). Electric Contacts: Theory and Applications. 4 ed., 482p. Uppsala: Almqvist and Wiksells Boktryckeri $\mathrm{AB}$

[5] PÕDRA, P., ANDERSSON, S. (1999): Simulating sliding wear with finite element method; Tribology International 32.

[6] SOUKUP, J., VOLEK, J. (2008). Non-stationary vibration of thin rectangular viscoelastic ortotropic plate IV. Applied and Computational Mechanics, Vol. 2, No. 2, University of West Bohemia Plzeň, Czech Republic,

[7] FABIAN, S., SALOKYOVÁ, Š., JACKO, P. Experimental verification of the frequency spectrum of unwears and wears guidance tube on the technological head vibrations creation in the production system with AWJ technology. In Manufacturing Technology, Vol. 12, No. 13, p. 105-108

[8] NOVÁK, P., MEŠKO, J., ŽMINDÁK, M. (2013). Finite Element Implementation of Multi-Pass Fillet Weld with Phase ganges. In Manufacturing Technology, Vol. 13, No. 1, p. 79-85

[9] JAKUBOVIČOVÁ, L. SÁGA, M., VAŠKO, M. (2013). Impact Analysis of Mutual Rotation of Roller Bearing Rings on the Process of Contact Stresses in Rolling Elements In Manufacturing Technology, Vol. 13, No. 1, p. 5054 